UDC: 336.7

JEL: D53; G01; G11

S. Ghosh ${ }^{1}$, T. Chakraborty ${ }^{2}$

\title{
ACTIVE INVESTMENT AND INVESTING ACTIVELY: AN EMPIRICAL STUDY OF INDIAN STOCK MARKET
}

\author{
${ }^{1}$ Shri Shikshayatan College, Kolkata, 11, Lord Sinha Road, Kolkata-71, India \\ ${ }^{2}$ University of Calcutta, 87/1, College Street, Kolkata-73, India
}

The stock market fluctuations sometimes perplex investors regarding their investment as it may lead to loss of their hard earned money. The different phases the market goes through is a matter of great concern for an investor. Portfolio management is a dynamic concept as it requires periodic review due to frequent changes in information flows, money flows, and economic and non-economic forces operating in the country on the securities markets. This means that the portfolio created during a particular market situation may not prove to be beneficial in other market situations. Hence a proper risk return analysis in every situation is required in order to maintain the flow of positive return from the portfolio. In this regard, the paper aims at constructing portfolios during different market phases. It also depicts how it is possible to earn a positive return from the portfolio during any phase of the market.

Keywords: investment, large cap, mid cap, small cap, portfolio, market phases, BSE Sensex.

\section{АКТИВНОЕ ИНВЕСТИРОВАНИЕ И ИНВЕСТИЦИОННАЯ АКТИВНОСТЬ: ЭМПИРИЧЕСКОЕ ИССЛЕДОВАНИЕ ФОНДОВОГО РЫНКА ИНДИИ}

\author{
Ш丷. Гош ${ }^{1}$, T. Чакраборти ${ }^{2}$ \\ ${ }^{1}$ Шри Шикшаятан колледж, Колката, 11, Лорд Синха роуд, Колката-71, Индия \\ 2 Университет Калькутты, 87/1, Колледж стрит, Колката-73, Индия
}

Колебания на фондовом рынке порой ставят инвестора в тупик в отношении инвестирования, так как они могут привести к потере с трудом заработанных денег. Различные фазы, которые проходит рынок, вызывают серьезное беспокойство у инвестора. Управление портфелем - динамическая концепция, требующая периодического пересмотра из-за частых изменений информационных и денежных потоков, а также экономических и неэкономических факторов, действующих на рынках ценных бумаг. Это означает, что портфель, сформированный в одной рыночной ситуации, в другой может оказаться невыгодным. Следовательно, для поддержания положительной доходности портфеля в каждой конкретной ситуации требуется корректный анализ соотношения степени риска и нормы прибыли. В связи с этим целью настоящего исследования является формирование инвестиционного портфеля на разных фазах рынка. В статье также показано, как на любой фазе рынка можно получить положительную доходность портфеля.

Ключевые слова: инвестиции, большая капитализация, средняя капитализация, малая капитализация, портфель, фазы рынка, BSE Sensex.

( Санкт-Петербургский государственный университет, 2018 


\section{INTRODUCTION}

Investment in share market is increasingly gaining importance among retail investors in India with more and more public awareness about securities and share market. Investment in shares is an active investment in the sense that the stock market has always an inherent quality of being volatile and active, while for an investor who invests in stocks, he needs to be active all the time in order to maintain and safeguard his portfolio from incurring sudden losses. The uncertainties or risks prevailing in the financial markets may result in incurring loss or reduced return on the portfolios of investors. Such uncertainty or risk relating to an individual security comprises two components, the market related risk called systematic risk, and the unique risk of that particular security called unsystematic risk. Systematic risks are the unavoidable or uncontrollable factors that affect the entire industry like market risk caused due to market cycles, i.e., demand and supply pressures, structural changes in the economy, tax law changes, recession, wars, etc. They tend to cause the share prices of nearly all individual companies to move together in the same direction. Unsystematic risks, on the other hand, arise due to controllable or internal factors of the business like weaknesses in basic operations of the business, debt-equity mix, etc. Hence, they are generally independent of factors affecting stock markets in general. So, adding more and more securities to a portfolio may cancel out this unsystematic risk specific to different securities, but the systematic risk would still remain and cannot be eliminated altogether. The aim of diversification is to reduce total risk without sacrificing portfolio return. The portfolio that provides the highest return for a given risk or the lowest risk for a given return in accordance with risk-return appetite of the investor is known as the optimal portfolio.

The conceptual framework and analytical tools for determining the optimal portfolio in a disciplined and objective manner is given by H.Markowitz [Markowitz, 1952] popularly known as "Modern Portfolio Theory". Undoubtedly, in order to diversify the unsystematic risks involved in investment, it is necessary to diversify a portfolio of securities across different sectors so that the risk from investment is minimized or eliminated, and the returns are maximized. However, the impact of diversification on the overall risk of the portfolio depends on the interactive risk, i.e., how the returns of a security move with the returns of other securities in the portfolio as indicated by the covariance of the securities returns. On the other hand, the correlation also helps in indicating the relation between the securities which in turn helps in deciding the best combination of securities to be included in the portfolio. In this context, a review of literature is attempted in the next section to throw light on the research that has been conducted so far in relation to portfolio diversification in India and abroad. The third section draws the objectives of the study, while the fourth one sketches the methodology of the analysis done. The fifth section is devoted to the analysis and findings of the study, and the last section draws the concluding observations. 


\section{LITERATURE REVIEW}

Portfolio theory provides with a broad understanding of the risk-return tradeoffs and the benefits of diversification. J.Evans and S.Archer [Evans, Archer, 1968] measured portfolio risk by the standard deviation of its returns from average return. The study assumed equal investment in all securities in the portfolio, which is optimum if the investor has no information about future returns' variances and co-variances. They concluded that for a randomly selected and equally weighted portfolio, there is very little diversification benefit beyond eight to ten stocks. On the other hand, W. Goetzmann and A. Kumar [Goetzmann, Kumar, 2008] pointed out that investors' portfolio holding with multiple stocks may not be truly diversified because the correlations in returns among the stocks within such portfolio can be fairly high. I. Meric, M. Ratner, and G. Meric [Meric, Ratner, Meric, 2008] found that the global diversification in the bull market of the same sector is better than diversification in an individual market with different sectors. In fact, global diversification is particularly important in the bear market conditions when almost all sectors in the local/domestic market become positively correlated, and hence global diversification would help provide cushion against losses.

In Indian context, the investment decision making process of individuals has been explored through experiments by S. Barua and G. Srinivasan [Barua, Srinivasan, 1987; 1991], and S. Barua and V. Raghunathan [Barua, Raghunathan, 1986]. They concluded that the risk perception of individuals is significantly influenced by the skewness of the return distribution. This implies that while taking investment decisions, investors are concerned about the possibility of maximum losses in addition to the variability of returns. R. Gupta [Gupta, 1991] argued that designing a portfolio for a client is much more than merely picking up securities for investment. The portfolio manager needs to understand the psyche of his client while designing his portfolio. According to him, investors in India regard equity, debentures and company deposits as being in more or less the same risk category, and consider mutual funds, including all equity funds, almost as safe as bank deposits.

Empirically, G. Sanyal and S. Sen [Sanyal, Sen, 1998] found that in India, where the market is not as efficient as western markets, 75 stocks make a better portfolio. In other studies, J. Varma [Varma, 1991] compared the Bombay Stock Exchange (BSE) National Index (Natex), which comprises 100 scrips, with the Sensitive Index (Sensex) comprising 30 scrips and concluded that the Natex is a sluggish index which responds too slowly to market conditions. Changes which are reflected in the Sensex on any day are completely reflected in the Natex only by the next day. He found that Sensex is more volatile than Natex. He therefore inferred that those who follow the Natex because of its greater comprehensiveness and theoretical appeal may be mistaken. The Sensex needs to be taken more seriously as a sound market index.

Likewise, several other research works have been done in this area, but published work on creation of a weighted portfolio of shares to yield a positive return during different phases of market situation has not appeared in literature yet. The present study, 
therefore, aims at fulfilling this vacuum. The study aims to: 1) construct portfolios of shares which generate positive returns in different phases of market situation; 2) analyse the impact of state initiative on stock price performance and hence its role in creation of portfolio; 3 ) analyse the composition of portfolios with Large Cap, Mid Cap and Small Cap stocks; and test the performance of the constructed portfolios of shares based on the following hypothesis.

Hypothesis $H_{0}$. The designed portfolio does not outperform market index.

\section{METHODOLOGY}

Period of study. Based on the impact of sub prime financial crisis and the resultant economic slowdown on the Indian stock market and its effect on BSE Sensex during the year 2007 to 2008, a full cycle period of 16 years from January 2000 to December 2015 is divided into three phases. The first phase from January 2000 to December 2006 is termed as the pre-slowdown period, the second phase - January 2007 to December 2009 as the slowdown period, and the third phase from January 2010 to December 2015 as the postslowdown period, along with a full cycle period considered for the entire period.

Sample selection. The sample of shares consists of 40 stocks constituting "BSE Sensex" with replacements over the entire period of study, i.e., 2000-2015, except for the post-slowdown period (2010-2015) and full cycle period (2000-2015) for each of which 38 stocks are considered since Sesa Goa has merged with Vedanta Ltd. and stocks of Sesa Goa are not traded on BSE from 2013 onwards, while Ranbaxy Laboratories has merged with Sun Pharmaceuticals and stocks of Ranbaxy Laboratories are delisted from all the Indian stock exchanges since April 2015 (Appendix). The sample, however, includes 32 Large Cap stocks (i.e., stock whose market capitalization ranges between Rs. 200 billion to Rs. 3500 billion), two Mid Cap stocks (i.e., stock whose market capitalization ranges between Rs. 50 billion to Rs. 200 billion), and one Small Cap stock (i.e., stock whose market capitalization lies below Rs. 50 billion) (www.bseindia.com). Out of the rest five stocks, Castrol India Ltd. was a Mid Cap stock till June 2010 and then it got included in Large Cap stocks due to increase in its capital base, and similarly Colgate Palmolive Ltd. was also a Mid Cap stock till October 2005 and then it entered into Large Cap category, Sesa Goa Ltd. belonged to Mid Cap category till November 2005 and thereafter got included in Large Cap category. Novartis India Ltd., which was a Small Cap stock till June 2008, got included in Mid Cap category later. NIIT Ltd. was a Small Cap stock till October 2005 and turned into a Large Cap stock afterwards.

Data type and data source. Secondary data relating to monthly closing prices of shares for the period January 2000 - December 2015 are collected from the relevant website of Bombay Stock Exchange (www.bseindia.com).

Softwares used. To analyse the data and construct portfolios, and for carrying out various calculations, LINGO and SPSS softwares are used. MS-Excel is also used for carrying out different operations and plotting graphs and creating tables.

Steps in Research. To achieve the research objectives, the following steps are adopted. 
1. Lognormal Return (i.e., $\ln \left(P_{1} / P_{0}\right)$ where $P_{1}$ is current month's share price and $P_{0}$ is immediately preceding month's price), in order to take the compounding effect into consideration, is calculated from the monthly closing prices of shares. Thereafter, descriptive statistics of the return series (such as Minimum, Maximum, Mean, Standard Deviation, Variance, Skewness, Kurtosis) are derived for each of the phases to assess the basic characteristics of the data set.

2. Covariance matrix is constructed between the selected stocks for each time phases in order to understand the comovement between the stocks' returns.

3. Then, LINGO portfolio optimization program is run using the return series derived for each share and the covariance matrix between the shares, given a target minimum return (which is equal to the lowest individual return value of all the stocks considered for a particular phase) for each of the three different phases and full cycle period to find out the weights to be assigned to the shares selected in the optimal portfolio. The general optimization expression to minimize risk with ' $n$ ' number of stocks in diversified portfolio is as follows:

$$
\text { Minimize } \sigma_{p}^{2}=\sum_{i=1}^{n} \sum_{i=1}^{n} w_{i} w_{j} \operatorname{Cov}_{i j}
$$

subject to:

$$
\begin{aligned}
& \sum_{i=1}^{n} w_{i}=1 ; \\
& \sum_{i=1}^{b} w_{i} \bar{R}_{i} \geq \bar{R}_{p} ; \\
& w_{1}, w_{2}, \ldots, w_{n} \geq 0,
\end{aligned}
$$

where:

$\sigma_{p}^{2}$ is the portfolio variance measuring portfolio risk;

$\sigma_{\mathrm{i}}^{2}=\operatorname{Cov}_{i i}$ are the variances in returns of $i$-individual stock in the portfolio;

$w_{1}, w_{2}, \ldots, w_{n}$ are the weights assigned to individual stocks;

$i=1,2, \ldots, n$;

$\bar{R}_{1}, \bar{R}_{2}, \ldots, \bar{R}_{n}$ are the mean returns on individual stocks;

$\sum_{i=1}^{n} w_{i} \bar{R}_{i}$ is the Portfolio Return, and

$\bar{R}_{p}$ is the desired level of expected return (i.e., target minimum return) from the Portfolio.

4. In the light of Markowitz Principle, portfolio return $\left(\bar{R}_{p}=w_{1} \bar{R}_{1}+\ldots+w_{n} \bar{R}_{n}\right.$, where $w_{1}, w_{2}, \ldots, w_{n}$ are the weights assigned to n-number of individual stocks selected in the optimal portfolio by LINGO and $\bar{R}_{1}, \bar{R}_{2}, \bar{R}_{n}$ are the mean returns on such ' $n$ ' individualstocks), and portfolio risk $\left(\sigma_{\mathrm{p}}=\sqrt{\sum_{i=1}^{n} \sum_{j=1}^{n} w_{i} w_{j} \sigma_{i} \sigma_{j} r_{i j}}\right.$, where $\sigma_{1}, \sigma_{2}, \ldots, \sigma_{\mathrm{n}}$ are the 
standard deviations of $n$-optimal stocks in the portfolio and $r_{i j}, i \neq \mathrm{j}$ are the correlations between the selected stocks in the portfolio, $r_{i i}=1$ ) are determined under each phase to compare the same with individual return and risk of the optimal stocks for the said phase.

To evaluate the performance of the constructed portfolios vis-à-vis market index, and test the null hypothesis outlined in section 3, the following steps are undertaken:

5. Beta value is calculated for each stock in model portfolio in order to determine the extent of sensitivity of the stocks to market movement. Then portfolio beta is calculated as the weighted average of beta values of individual stocks comprising the designed portfolio to find out the extent of systematic risk in the model portfolio.

6. Portfolio return for each phase is compared with BSE Sensex return by plotting graph using MS-Excel.

7. Thereafter, to evaluate portfolio performance, Sharpe ratio is calculated for each optimal portfolio of stocks for each phase by determining the excess return earned on the portfolio per unit of volatility or total risk as follows.

$$
\text { Sharpe Ratio }=\left(\bar{R}_{p}-R_{f}\right) / \sigma_{p} \text {, }
$$

where:

$$
\begin{aligned}
& \bar{R}_{p}=\text { Mean portfolio return; } \\
& R_{f}=\text { Risk free rate = Treasury Bill Return }=4,60 \% \text { p.a. }(\text { during the period of } \\
& \text { study); } \\
& \sigma_{p}=\text { Portfolio standard deviation. }
\end{aligned}
$$

Sharpe ratio for stock market index can be calculated in a similar way by substituting mean and standard deviation of index return in place of portfolio return. If Sharpe ratio for portfolio is greater than Sharpe ratio for stock market index, then it implies that the designed portfolio outperforms index thereby rejecting null hypothesis; otherwise accepting null.

8. Finally, tracking error, also known as active risk, is calculated for each optimal portfolio of shares created for each phase with respect to benchmark return, i.e., BSE Sensex return to find out how closely it follows the market. There is no universal standard of acceptable limit of tracking error, but it is always acceptable to have a low tracking error with positive excess returns. Also, the lower the tracking error, the more closely it resembles the market index which, in turn, implies that the designed portfolio is well diversified. Tracking error is calculated using the following formula:

$$
\text { Tracking Error }=\sigma\left(R_{P}-R_{B}\right) \text {, }
$$

where:

$\sigma=$ Standard Deviation of difference between portfolio return and benchmark return;

$R_{P}=$ Portfolio Return;

$R_{B}=$ Benchmark Return, i.e., Sensex Return ${ }^{1}$.

${ }^{1}$ Sensex is the barometer index of the Bombay Stock Exchange (BSE). It is a free-float market weighted stock market index of 30 well established and financially sound companies listed on BSE. 


\section{ANALYSIS AND FINDINGS}

The findings of the empirical analysis during the different phases are presented below.

Pre-slowdown period (2000-2006). The descriptive statistics of 40 stocks for the pre-slowdown period shows that Sesa Goa Ltd. has the highest mean followed by ICICI Bank, while ITC has got the maximum variance in its stock returns during this period. Running LINGO optimization on the 40 stocks yields the following results (Table 1).

Table 1. Weighted portfolio of stocks, 2000-2006

\begin{tabular}{|c|c|c|c|c|c|c|c|}
\hline $\begin{array}{l}\text { Assets } \\
\text { (1) }\end{array}$ & $\begin{array}{c}\begin{array}{c}\text { Category } \\
\text { of } \\
\text { capitalization }\end{array} \\
(2)\end{array}$ & $\begin{array}{c}\text { Weights } \\
\text { (3) }\end{array}$ & $\begin{array}{l}\text { Mean } \\
\text { return } \\
(4)\end{array}$ & $\begin{array}{l}\text { Weighted } \\
\text { return in } \\
\text { portfolio } \\
(5)=(3) \star(4)\end{array}$ & $\begin{array}{l}\text { Risk } \\
(\sigma) \\
(6)\end{array}$ & $\begin{array}{l}\text { Beta } \\
(\beta)^{\dagger} \\
(7)\end{array}$ & $\begin{array}{l}\begin{array}{l}\text { Weighted } \\
\text { beta }\end{array} \\
(8)=(3) \star(7)\end{array}$ \\
\hline $\begin{array}{l}\text { CASTROL_ } \\
\text { INDIA_LTD }\end{array}$ & MID & 0,04 & $-0,00347$ & $-0,000138$ & 0,09562 & 0,62393 & 0,024957 \\
\hline $\begin{array}{l}\text { COLGATE_- } \\
\text { PALMOLIVE_ } \\
\text { LTD }\end{array}$ & MID & 0,03 & 0,00710 & 0,000213 & 0,08135 & 0,50249 & 0,015075 \\
\hline DR REDDY_S_LAB & LARGE & 0,07 & $-0,00685$ & $-0,000479$ & 0,12990 & 0,37807 & 0,026465 \\
\hline HDFC & LARGE & 0,08 & 0,01997 & 0,001598 & 0,10991 & 0,64398 & 0,051519 \\
\hline HDFC_BANK_LTD & LARGE & 0,09 & 0,02251 & 0,002026 & 0,08677 & 0,53993 & 0,048593 \\
\hline HUL & LARGE & 0,04 & $-0,02787$ & $-0,001114$ & 0,27556 & 1,41769 & 0,056708 \\
\hline $\begin{array}{l}\text { NESTLE_INDIA_ } \\
\text { LTD }\end{array}$ & LARGE & 0,40 & 0,01157 & 0,004628 & 0,07236 & 0,08919 & 0,035674 \\
\hline RANBAXY_LAB & MID & 0,04 & $-0,01096$ & $-0,000438$ & 0,14747 & 0,63675 & 0,025469 \\
\hline RIL_RPL & LARGE & 0,15 & 0,02029 & 0,003044 & 0,09489 & 0,83862 & 0,125793 \\
\hline $\begin{array}{l}\text { GLAXO_ } \\
\text { SMITHKLINE_ } \\
\text { PHARMA }\end{array}$ & LARGE & 0,02 & 0,00555 & 0,000111 & 0,10105 & 0,70717 & 0,014143 \\
\hline \begin{tabular}{|l|} 
AMBUJA_- \\
CEMENT \\
\end{tabular} & LARGE & 0,02 & $-0,00995$ & $-0,000199$ & 0,24623 & 0,71944 & 0,014389 \\
\hline INFOSYS_LTD & LARGE & 0,02 & $-0,02009$ & $-0,000401$ & 0,20754 & 0,96399 & 0,019279 \\
\hline \begin{tabular}{|l|} 
Portfolio \\
\end{tabular} & & 1 & & 0,008851 & 0,04513 & & \\
\hline Portfolio Beta & & & & & & & 0,458064 \\
\hline
\end{tabular}

$\mathrm{N}$ o t e: $\dagger-$ Beta $(\beta)$ is the measure of volatility or systematic risk of a security or portfolio in comparison to the market.

Table 1 shows that out of 40 stocks, only 12 stocks, including 9 Large Cap stocks and 3 Mid Cap stocks, are selected by LINGO to comprise minimum risk portfolio during 
pre-slowdown phase. The table further reveals the optimum weights assigned to those 12 stocks with their mean return and risk, and total return and risk of the portfolio. Maximum weight is assigned to Nestle India Ltd. $(0,40)$, followed by Reliance Industries $(0,15)$. And overall it may be noted that total return on the Portfolio is positive with a risk lower than all the individual risks of the constituent stocks in the portfolio which may be due to the diversification of the portfolio. Hence it may be said that diversification benefit is achieved. Moreover, the beta $(\beta)$ of the portfolio being less than 1 ( $\beta_{P}$ $=0,46)$ suggests that the portfolio is a defensive one which may act as a guard against excess volatility in the market.

The comparison of model portfolio with BSE Sensex during pre-slowdown period (2000-2006) is revealed in Figure 1 below. It shows that the total return from the portfolio almost track the BSE Sensex during the pre-slowdown period.

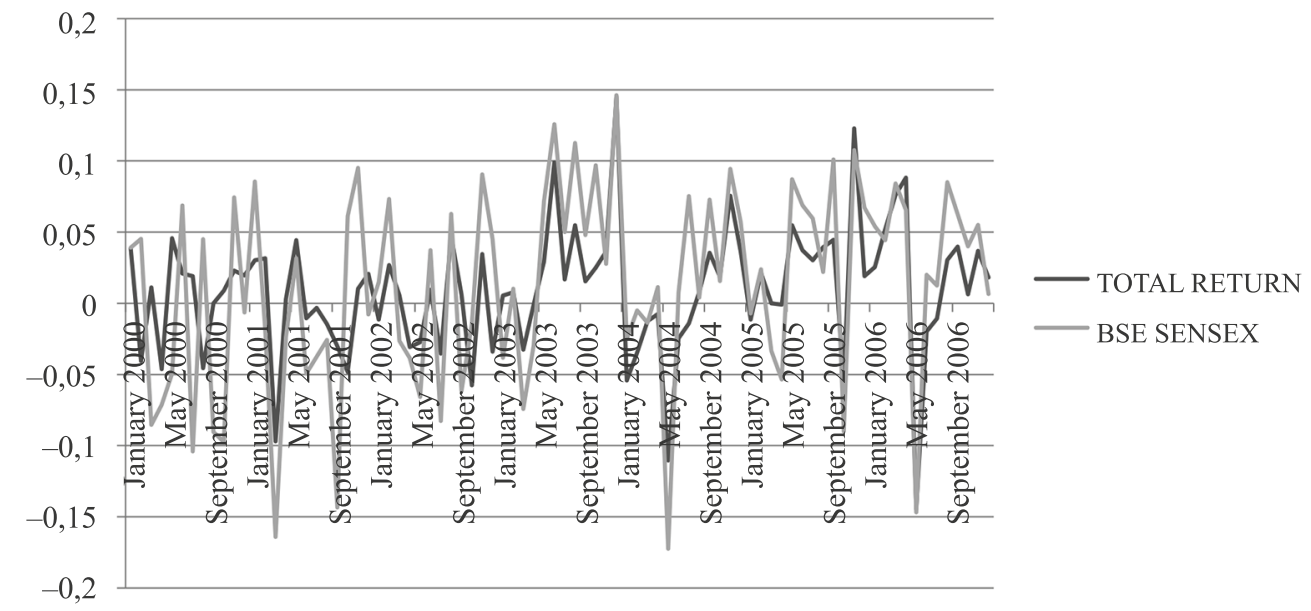

Figure 1. Total return from portfolio vis-a-vis Sensex Return, January 2000 - December 2006

In order to test the efficiency of the portfolio, Sharpe Ratio and Tracking Error are calculated as shown below (Table 2).

Table 2. Portfolio performance evaluation, 2000-2006 (Sharpe ratio and Tracking error)

\begin{tabular}{|l|c|c|c|}
\hline \multicolumn{1}{|c|}{ Particulars } & Portfolio & BSE Sensex & \\
\hline $\begin{array}{l}\text { Excess of average portfolio return over } \\
\text { risk free return }\end{array}$ & 0,060148 & 0,098731 & \\
\hline Standard deviation $(\sigma)$ of portfolio return & 0,196434 & 0,298092 & \\
\hline Sharpe ratio & $\mathbf{0 , 3 0 6 2 0 1}$ & $\mathbf{0 , 3 3 1 2 1 0}$ & \\
\hline Tracking error (monthly) & & & $\mathbf{0 , 0 4 9 4 1 3}$ \\
\hline
\end{tabular}


The Sharpe ratio of the constructed portfolio and BSE Sensex in table 2 shows that the ratio for the portfolio is less than that of Sensex, although with a negligible difference. Here, although the hypothesis $H_{0}$ cannot be rejected since the portfolio is not able to outperform the market, but from the previous calculation it can be found that Portfolio Beta is less than $1\left(\beta_{P}<1\right)$ which suggests that the constructed portfolio is efficient enough to shield the investors against excess volatility in the market and thereby incurring significant losses. In addition, the tracking error is also quite low, i.e., $4,9 \%$, which further shows that the portfolio tracks the benchmark index almost to a great extent.

Slowdown period (2007-2009). The slowdown period considered for the study is the period during which BSE Sensex ${ }^{2}$ has started showing a declining trend. The descriptives of the 40 stocks during the slowdown period show that Castrol India Ltd. has the highest mean, with Sesa Goa Ltd. having the highest variance in the return on its securities, while Colgate Palmolive Ltd. and HUL have the lowest variance in return, i.e., $0,6 \%$.

LINGO optimization selects only 5 out of 40 stocks in the optimal weighted portfolio, with 4 stocks from the Large Cap category and only 1 stock from the Small Cap category as shown in Table 3 below.

It may be observed from the above table that the maximum weight is given to the stocks of Colgate Palmolive Ltd., followed by Glaxo Smithkline Pharmaceuticals Ltd.

Table 3. Weighted portfolio of stocks, 2007-2009

\begin{tabular}{|c|c|c|c|c|c|c|c|}
\hline $\begin{array}{l}\text { Assets } \\
\text { (1) }\end{array}$ & \begin{tabular}{|c|}
$\begin{array}{c}\text { Category } \\
\text { of } \\
\text { capitalization } \\
(2)\end{array}$ \\
\end{tabular} & $\begin{array}{c}\text { Weights } \\
\text { (3) }\end{array}$ & $\begin{array}{c}\text { Mean } \\
\text { return } \\
(4)\end{array}$ & $\begin{array}{l}\text { Weighted } \\
\text { return in } \\
\text { portfolio } \\
(5)=(3) \star(4)\end{array}$ & $\begin{array}{l}\text { Risk } \\
(\sigma) \\
(6)\end{array}$ & $\begin{array}{l}\text { Beta } \\
(\beta) \\
(7)\end{array}$ & $\begin{array}{l}\begin{array}{l}\text { Weighted } \\
\text { beta }\end{array} \\
(8)=(3) \star(7)\end{array}$ \\
\hline $\begin{array}{l}\text { BHARAT_HEAVY_ } \\
\text { ELECTRICALS_ } \\
\text { LTD }\end{array}$ & Large Cap & 0,072 & 0,00128 & 0,000090 & 0,151007 & 0,79523 & 0,057257 \\
\hline $\begin{array}{l}\text { COLGATE_ } \\
\text { PALMOLIVE_LTD }\end{array}$ & Large Cap & 0,420 & 0,01468 & 0,006166 & 0,076924 & 0,19671 & 0,082619 \\
\hline $\begin{array}{l}\text { GLAXO_ } \\
\text { SMITHKLINE_ } \\
\text { PHARMA }\end{array}$ & Large Cap & 0,252 & 0,00900 & 0,002268 & 0,087730 & 0,21321 & 0,053729 \\
\hline $\begin{array}{l}\text { NOVARTIS_ } \\
\text { INDIA_LTD }\end{array}$ & Small Cap & 0,068 & 0,01250 & 0,000850 & 0,115751 & 0,59801 & 0,040665 \\
\hline $\begin{array}{l}\text { SUN_- } \\
\text { PHARMACUETICALS_ } \\
\text { INDUSTRIES }\end{array}$ & Large Cap & 0,188 & 0,01198 & 0,002252 & 0,086368 & 0,48397 & 0,090986 \\
\hline Portfolio & & 1 & & 0,011626 & 0,050007 & & \\
\hline Portfolio Beta & & & & & & & 0,325255 \\
\hline
\end{tabular}

2 BSE Sensex is the barometer index of Bombay Stock Exchange (BSE) comprising 30 stocks. 
The betas of the portfolio as well as individual stocks are lesser than the market beta (i.e., 1) indicating the nature of defensive portfolio. And even during the slowdown period, it is seen that the portfolio of stocks is yielding a positive return of $1,16 \%$ with a risk lower than the individual risks of all the constituent stocks in the portfolio, thereby providing benefits of diversification.

The comparison between model portfolio with BSE Sensex during slowdown period (2007-2009) in Figure 2 below shows how the portfolio return tracks the Sensex return during this period.

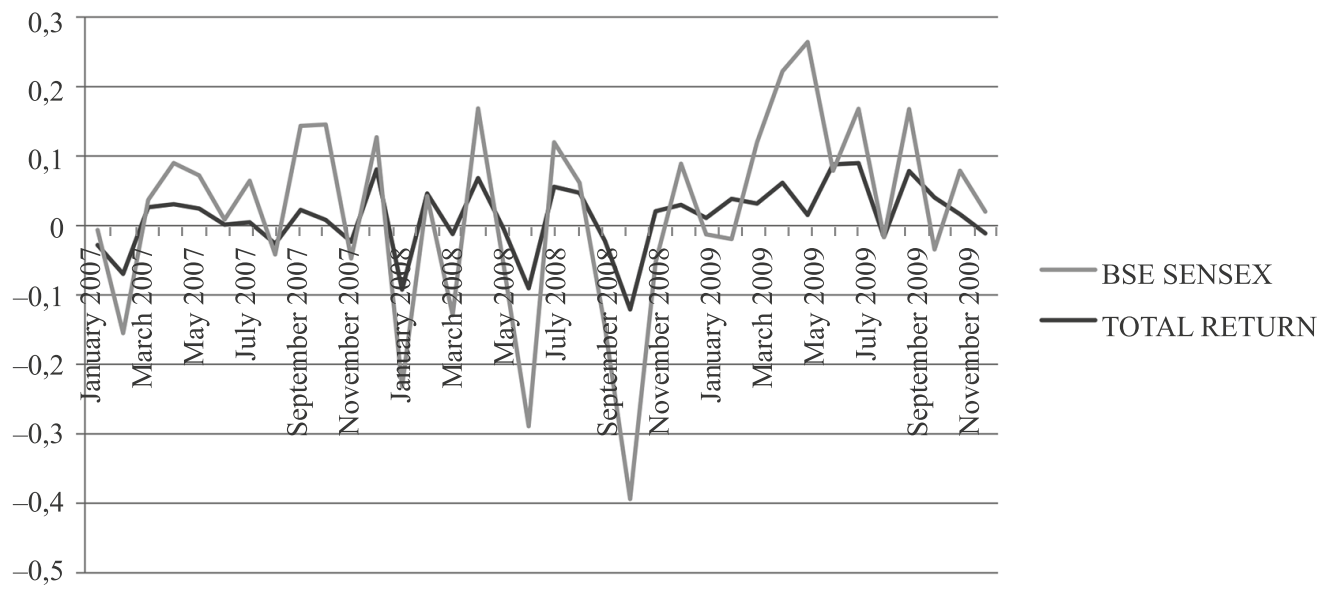

Figure 2. Total returns from portfolio vis-a-vis Sensex Return, January 2007 - December 2009

Table 4 below portrays the efficiency of the portfolio through Sharpe ratio and it may be interpreted that the portfolio formed with the assigned weights outperforms the Sensex to a great extent which rejects the null hypothesis in this phase. The tracking error of $7,84 \%$ also shows that the portfolio is able to track the market to a sufficient extent.

Table 4. Portfolio performance evaluation, 2007-2009 (Sharpe ratio and Tracking error)

\begin{tabular}{|l|c|c|c|}
\hline \multicolumn{1}{|c|}{ Particulars } & Portfolio & BSE Sensex & \\
\hline $\begin{array}{l}\text { Excess of average portfolio return over risk } \\
\text { free return }\end{array}$ & 0,093537 & 0,032823 & \\
\hline Standard deviation $(\sigma)$ of portfolio return & 0,268119 & 0,719481 & \\
\hline Sharpe ratio & $\mathbf{0 , 3 4 8 8 6 4}$ & $\mathbf{0 , 0 4 5 6 2 0}$ & \\
\hline Tracking error (monthly) & & & $\mathbf{0 , 0 7 8 4 4 1}$ \\
\hline
\end{tabular}


Therefore, it may be deduced from the above analysis that, even during the slowdown phase, if a well diversified portfolio of shares is formed, it is possible to earn positive return.

Post-slowdown period (2010-2015). After 2009, the Indian share market again started to rise, and observing such a phenomenon the post slowdown period is assumed to be from 2010 to 2015. During this period, it is noticed that HUL has the maximum mean return for its stocks, followed by that of Dr. Reddy's Lab, with maximum variance seen in the stock returns of Tata Power Co. Ltd. On the other hand, Nestle India Ltd. has the minimum variance in returns.

Table 5 below shows the diversified portfolio of stocks selected by LINGO with optimum weights assigned in order to get a positive return. It is observed that out of 38 sample stocks, the optimal portfolio consists of 16 stocks with maximum weight assigned to stocks of Dr. Reddy's Lab and Nestle India Ltd, followed by HUL and Wipro Ltd. Although it is seen that some of the stocks have negative individual mean returns during this phase, still they constitute the portfolio which may be due to their low variance in returns. It is further observed that most of the stocks comprising the optimal portfolio in

Table 5. Weighted portfolio of stocks, 2010-2015

\begin{tabular}{|l|c|c|c|c|c|c|c|}
\hline \multicolumn{1}{|c|}{ Assets } & $\begin{array}{c}\text { Category of } \\
\text { capitalization }\end{array}$ & Weights & $\begin{array}{c}\text { Mean } \\
\text { return }\end{array}$ & $\begin{array}{c}\text { Weighted } \\
\text { return } \\
\text { in portfolio }\end{array}$ & $\begin{array}{c}\text { Risk } \\
(\mathbf{\sigma})\end{array}$ & $\begin{array}{c}\text { Beta } \\
(\boldsymbol{\beta})\end{array}$ & $\begin{array}{c}\text { Weighted } \\
\text { beta }\end{array}$ \\
\hline $\begin{array}{l}\text { BHARAT_ } \\
\text { HEAVY_ } \\
\text { ELECTRICALS_LTD }\end{array}$ & Large Cap & 0,020 & $-0,03660$ & $-0,00073$ & 0,21855 & 0,65303 & 0,01306 \\
\hline $\begin{array}{l}\text { CASTROL_ } \\
\text { INDIA_LTD }\end{array}$ & $\begin{array}{c}\text { Mid Cap till } \\
\text { June 2010, then } \\
\text { Large Cap }\end{array}$ & 0,015 & $-0,00438$ & $-0,00007$ & 0,12927 & 0,43674 & 0,00655 \\
\hline $\begin{array}{l}\text { COLGATE_ } \\
\text { PALMOLIVE_LTD }\end{array}$ & Large Cap & 0,030 & 0,00559 & 0,00017 & 0,10065 & 0,27964 & 0,00839 \\
\hline DR REDDY S_LAB & Large Cap & 0,142 & 0,01386 & 0,00197 & 0,07159 & 0,35376 & 0,05023 \\
\hline GAIL_INDIA_LTD & Large Cap & 0,090 & $-0,00133$ & $-0,00012$ & 0,06984 & 0,72313 & 0,06508 \\
\hline $\begin{array}{l}\text { GLAXO_ } \\
\text { SMITHKLINE_ } \\
\text { PHARMA }\end{array}$ & Large Cap & 0,090 & 0,00995 & 0,00090 & 0,06465 & 0,23013 & 0,02071 \\
\hline $\begin{array}{l}\text { GRASIM_ } \\
\text { INDUSTRIES_LTD }\end{array}$ & Large Cap & 0,064 & 0,00564 & 0,00036 & 0,08222 & 0,91173 & 0,05835 \\
\hline HUL & Large Cap & 0,100 & 0,01642 & 0,00164 & 0,06543 & 0,53229 & 0,05323 \\
\hline ITC_LTD & Large Cap & 0,040 & 0,00352 & 0,00014 & 0,09212 & 0,46387 & 0,01856 \\
\hline
\end{tabular}


End of the table 5

\begin{tabular}{|l|c|c|c|c|c|c|c|}
\hline $\begin{array}{l}\text { MAHINDRA_ } \\
\text { MAHINDRA }\end{array}$ & Large Cap & 0,040 & 0,00226 & 0,00009 & 0,10418 & 0,63692 & 0,02548 \\
\hline $\begin{array}{l}\text { NESTLE_ } \\
\text { INDIA_LTD }\end{array}$ & Large Cap & 0,142 & 0,01137 & 0,00162 & 0,05125 & 0,42756 & 0,06071 \\
\hline $\begin{array}{l}\text { NOVARTIS_ } \\
\text { INDIA_LTD }\end{array}$ & Mid Cap & 0,050 & 0,00520 & 0,00026 & 0,07918 & 0,57627 & 0,02881 \\
\hline RIL_RPL & Large Cap & 0,060 & $-0,00102$ & $-0,00006$ & 0,07185 & 1,06413 & 0,06385 \\
\hline SBI & Large Cap & 0,014 & $-0,03188$ & $-0,00045$ & 0,26642 & 1,02592 & 0,01436 \\
\hline $\begin{array}{l}\text { SUN_ } \\
\text { PHARMACEUTICALS_ } \\
\text { INDUSTRIES }\end{array}$ & Large Cap & 0,003 & $-0,00845$ & $-0,00003$ & 0,20996 & 0,93108 & 0,00279 \\
\hline WIPRO_LTD & Large Cap & 0,100 & $-0,00269$ & $-0,00027$ & 0,10112 & 0,35988 & 0,03599 \\
\hline Portfolio & & $\mathbf{1}$ & & $\mathbf{0 , 0 0 7 1 5}$ & $\mathbf{0 , 0 3 2 1 4 7}$ & & \\
\hline Portfolio Beta & & & & & & & $\mathbf{0 , 5 2 6 1 5}$ \\
\hline
\end{tabular}

this period belong to the Large Cap category. The total return from the portfolio during this phase also shows a positive result with risk lower than all the individual risks of the stocks in the portfolio, thereby providing benefit of diversification. Moreover, apart from a few stocks like that of SBI and RPL, the beta coefficients for the rest of the stocks are all less than $1(\beta<1)$ indicating a lower volatility than the market.

A comparison of model portfolio with BSE Sensex during post slowdown phase (2010-2015) in Figure 3 below shows that the total return from portfolio almost tracks the Sensex return in each month with a little deviation.

Table 6 below shows that the Sharpe ratio of the portfolio is higher than the ratio on Sensex, which suggests that the constructed portfolio is more efficient than the Sensex thereby rejecting the null hypothesis.

Moreover, the tracking error shows that the portfolio is unable to track the market only to the extent of $3 \%$ which may again be substantiated by the fact from Table 5 that the portfolio beta is less than $1(\beta<1)$ indicating a defensive portfolio.

Full cycle (2000-2015). During this period, the maximum mean return $(1,35 \%)$ is observed for Nestle India Ltd., together with minimum variance in its return $(0,5 \%)$, among all 38 stocks sampled for the full cycle period. The maximum variance and minimum mean return is observed for NIIT Ltd.

Table 7 below shows that the optimal weighted portfolio consists of 13 out of 38 stocks, where maximum weight is assigned to Nestle India Ltd., followed by Glaxo Smithkline Pharmaceuticals and others. It may be noted that during the full cycle, all the constituent stocks of the portfolio belong to the Large Cap category except Castrol India 


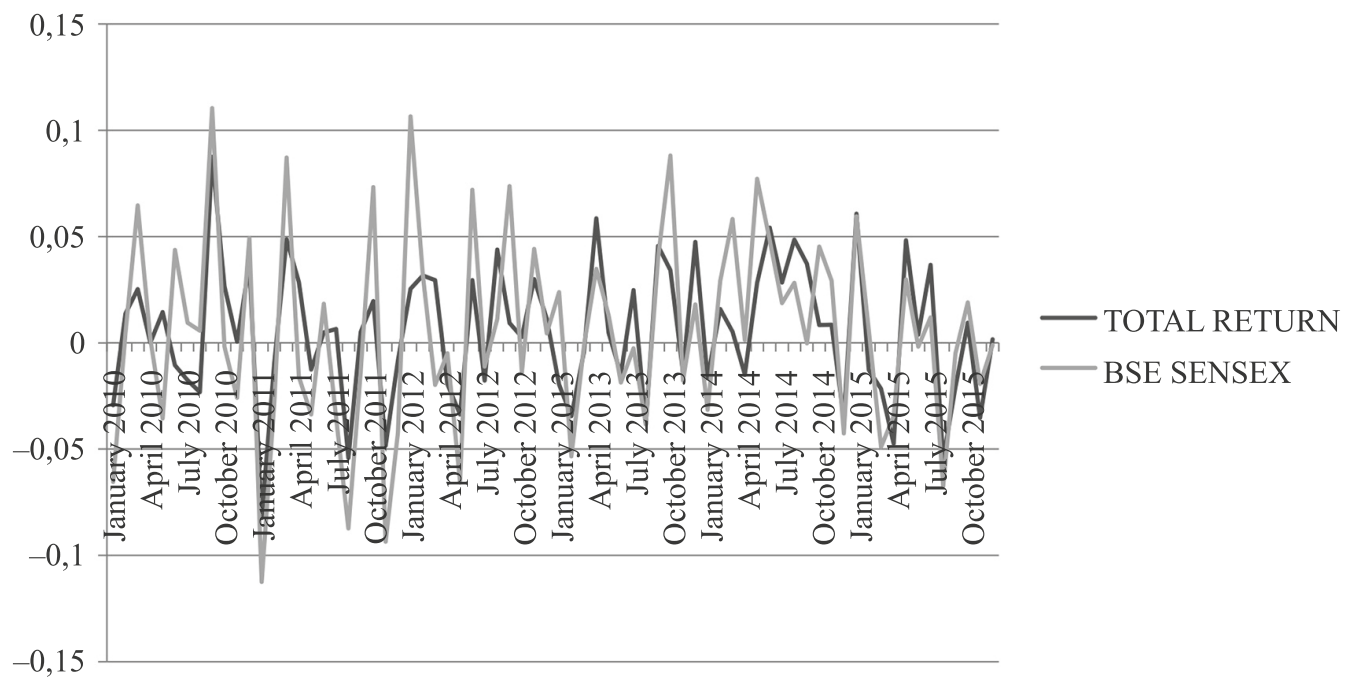

Figure 3. Total return from portfolio vis-a-vis Sensex return, January 2010 - December 2015

Table 6. Portfolio performance evaluation, 2010-2015 (Sharpe ratio and Tracking error)

\begin{tabular}{|l|c|c|c|}
\hline \multicolumn{1}{|c|}{ Particulars } & Portfolio & BSE Sensex & \\
\hline Excess of average portfolio return over risk free return & 0,019054 & 0,021070 & \\
\hline Standard deviation $(\sigma)$ of portfolio return & 0,107454 & 0,204770 & \\
\hline Sharpe ratio & $\mathbf{0 , 1 7 7 3 2 1}$ & $\mathbf{0 , 1 0 2 8 9 5}$ & \\
\hline Tracking error (monthly) & & & $\mathbf{0 , 0 3 0 1 7 4}$ \\
\hline
\end{tabular}

Ltd. and Colgate Palmolive Ltd. which were Mid Cap stocks till 2010 and 2005 respectively. Looking at the beta values of the portfolios constituent stocks it may be observed that all are defensive stocks except one, i.e., SBI. Overall, return on portfolio is positive and portfolio risk being lower than all individual risks of the stocks in the portfolio clearly signaling the effect of diversification.

Figure 4 below shows the total returns on model portfolio vis-a-vis Sensex return for the full cycle implementation phase and it may be drawn from the chart that the portfolio almost tracks the Sensex to a large extent.

Table 8 below further shows that the Sharpe ratio on portfolio is much higher than that of Sensex, which probably is due to the presence of all Large Cap stocks in the portfolio that has made the portfolio of stocks yield more return, and again the analysis results reject the null hypothesis in favour of the alternative hypothesis since the portfolio outperforms the market index. 


\begin{tabular}{|c|c|c|c|c|c|c|c|c|c|c|c|c|c|c|c|c|}
\hline 总 & 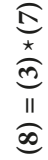 & $\begin{array}{l}10 \\
0 \\
0 \\
0 \\
0\end{array}$ & 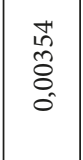 & $\begin{array}{l}\stackrel{\infty}{*} \\
\vec{\forall} \\
0\end{array}$ & \begin{tabular}{l}
$\infty$ \\
\multirow{0}{0}{} \\
0 \\
0 \\
0
\end{tabular} & $\begin{array}{l}\text { 过 } \\
\text { o } \\
0 \\
0\end{array}$ & $\begin{array}{l}0 \\
\stackrel{0}{0} \\
0 \\
0 \\
0\end{array}$ & $\begin{array}{l}8 \\
\text { O. } \\
0 \\
0 \\
0\end{array}$ & 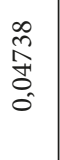 & $\begin{array}{l}0 \\
\infty \\
0 \\
0 \\
0 \\
0\end{array}$ & $\begin{array}{l}\overrightarrow{1} \\
\dot{0} \\
0 \\
0\end{array}$ & $\begin{array}{l}\text { oे } \\
\text { +े } \\
\text { ô } \\
0\end{array}$ & $\begin{array}{l}\stackrel{M}{\cong} \\
\Xi \\
0\end{array}$ & $\begin{array}{l}\text { 我 } \\
0 \\
0 \\
0\end{array}$ & & 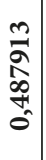 \\
\hline 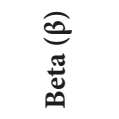 & $\mathbb{E}$ & $\begin{array}{l}+1 \\
\text { Oे } \\
0 \\
0 \\
0\end{array}$ & 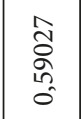 & $\begin{array}{l}0 \\
\stackrel{3}{m} \\
\stackrel{m}{0} \\
0\end{array}$ & \begin{tabular}{l}
0 \\
\multirow{2}{+}{} \\
5 \\
0 \\
0
\end{tabular} & \begin{tabular}{l} 
Na \\
\multirow{2}{*}{} \\
0
\end{tabular} & $\begin{array}{l}0 \\
0 \\
\circ \\
\infty \\
0\end{array}$ & 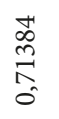 & $\begin{array}{l}3 \\
2 \\
\infty \\
\hat{0}\end{array}$ & 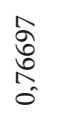 & $\begin{array}{l}\overrightarrow{0} \\
\hat{0} \\
\text { n. } \\
0\end{array}$ & $\begin{array}{l}0 \\
10 \\
\infty \\
11 \\
0 \\
0\end{array}$ & 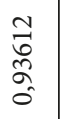 & $\begin{array}{l}\infty \\
\stackrel{n}{n} \\
0 \\
= \\
=\end{array}$ & & \\
\hline 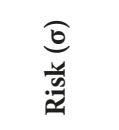 & (e) & $\begin{array}{l}n \\
\hat{2} \\
\\
-1 \\
0\end{array}$ & $\begin{array}{l}\text { Oे } \\
\stackrel{-}{=} \\
0 \\
0\end{array}$ & $\begin{array}{l}2 \\
2 \\
\infty \\
0 \\
0\end{array}$ & $\begin{array}{l}\frac{1}{a} \\
a \\
0 \\
0\end{array}$ & $\begin{array}{l}0 \\
8 \\
0 \\
0 \\
0 \\
0\end{array}$ & $\begin{array}{l}\vec{T} \\
\text { It } \\
\hat{0}\end{array}$ & 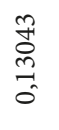 & 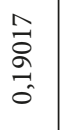 & $\begin{array}{l}\frac{10}{2} \\
\stackrel{2}{1} \\
0\end{array}$ & 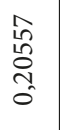 & $\begin{array}{l}\tilde{n} \\
\hat{\delta} \\
0 \\
0\end{array}$ & $\begin{array}{l}\stackrel{0}{1} \\
\hat{0} \\
\stackrel{0}{0}\end{array}$ & $\begin{array}{l}\mathfrak{m} \\
\infty \\
\infty \\
0 \\
0\end{array}$ & \begin{tabular}{l}
$\pi$ \\
$\hat{0}$ \\
\multirow{2}{*}{} \\
0 \\
0
\end{tabular} & \\
\hline 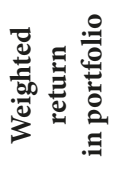 & 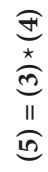 & $\begin{array}{l}4 \\
10 \\
8 \\
0 \\
0 \\
0 \\
1\end{array}$ & $\begin{array}{l}\mathfrak{1} \\
\vdots \\
\vdots \\
0 \\
0\end{array}$ & $\begin{array}{l}10 \\
2 \\
\hat{2} \\
8 \\
0 \\
0\end{array}$ & $\begin{array}{l}2 \\
\hat{\delta} \\
\delta \\
0 \\
0\end{array}$ & $\begin{array}{l}\hat{1} \\
\\
\overline{8} \\
0 \\
0\end{array}$ & $\begin{array}{l}\infty \\
2 \\
0 \\
0 \\
0 \\
0\end{array}$ & $\begin{array}{l}\text { ले } \\
\text { ठ̊ } \\
8 \\
0 \\
0\end{array}$ & $\begin{array}{l}0 \\
0 \\
8 \\
0 \\
0 \\
0 \\
1\end{array}$ & $\begin{array}{l}\text { ते } \\
\text { ऽิ } \\
\delta \\
0 \\
0\end{array}$ & 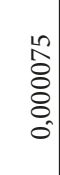 & $\begin{array}{l}8 \\
8 \\
0 \\
0 \\
0 \\
0\end{array}$ & $\begin{array}{l}\tilde{2} \\
\hat{\delta} \\
\delta \\
0 \\
0\end{array}$ & $\begin{array}{l}\overline{8} \\
8 \\
0 \\
0\end{array}$ & 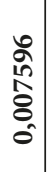 & \\
\hline 胥吾 & $\overparen{\nexists}$ & 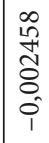 & 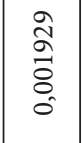 & $\begin{array}{l}n \\
2 \\
\hat{人} \\
0 \\
0 \\
0\end{array}$ & $\begin{array}{l}\tilde{\alpha} \\
\text { ळे } \\
0 \\
0\end{array}$ & $\begin{array}{l}\frac{1}{1} \\
\infty \\
\stackrel{0}{0} \\
0 \\
0\end{array}$ & 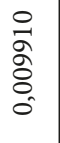 & 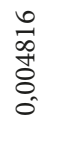 & 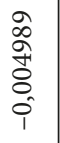 & 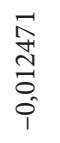 & $\begin{array}{l}\hat{n} \\
\hat{n} \\
\hat{\sigma} \\
0 \\
0 \\
i\end{array}$ & $\begin{array}{l}\tilde{N} \\
\hat{n} \\
0 \\
0 \\
0 \\
0\end{array}$ & $\begin{array}{l}\text { मे } \\
\stackrel{0}{\circ} \\
8 \\
0 \\
0\end{array}$ & 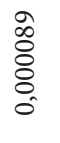 & & \\
\hline $\begin{array}{l}\stackrel{0}{0} \\
\frac{00}{000} \\
3\end{array}$ & () & స్ & 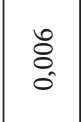 & $\begin{array}{l}\stackrel{1}{1} \\
\text { ó }\end{array}$ & $\begin{array}{l}8 \\
\stackrel{1}{0} \\
0\end{array}$ & $\begin{array}{l}0 \\
\text { in } \\
\text { ó }\end{array}$ & 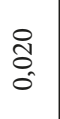 & $\hat{0}$ & $\begin{array}{l}8 \\
\stackrel{0}{0}\end{array}$ & $\begin{array}{l}\text { तิ } \\
\text { రิ }\end{array}$ & 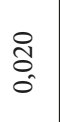 & $\begin{array}{l}\text { 울 } \\
\text { n. } \\
0\end{array}$ & $\begin{array}{l}\text { तิ } \\
\text { ô }\end{array}$ & $\begin{array}{l}m \\
0 \\
0\end{array}$ & - & \\
\hline 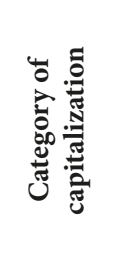 & $\widehat{d}$ & 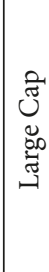 & 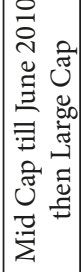 & 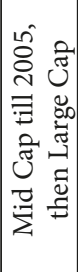 & 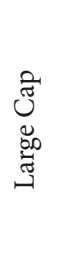 & 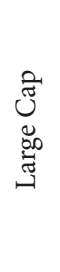 & 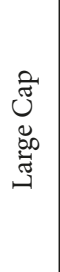 & 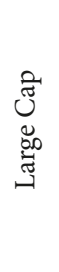 & 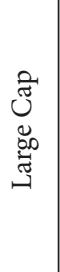 & 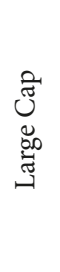 & 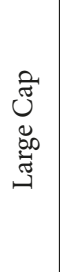 & 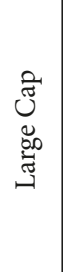 & 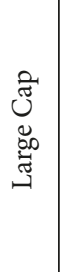 & 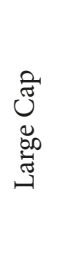 & & \\
\hline 营 & $\Xi$ & 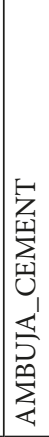 & 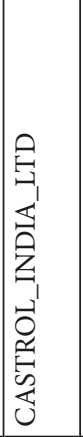 & 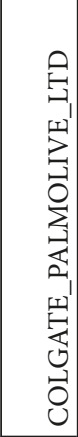 & 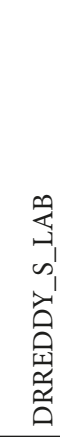 & 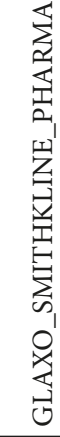 & 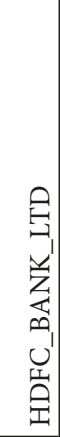 & 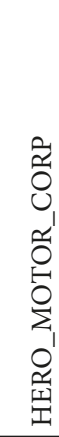 & 定 & 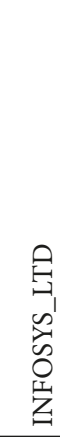 & 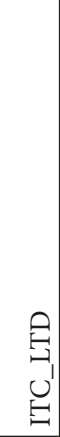 & 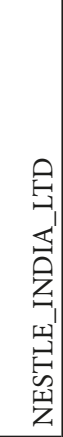 & 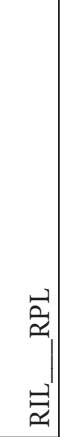 & $\vec{m}$ & 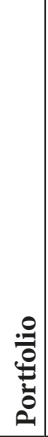 & 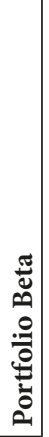 \\
\hline
\end{tabular}




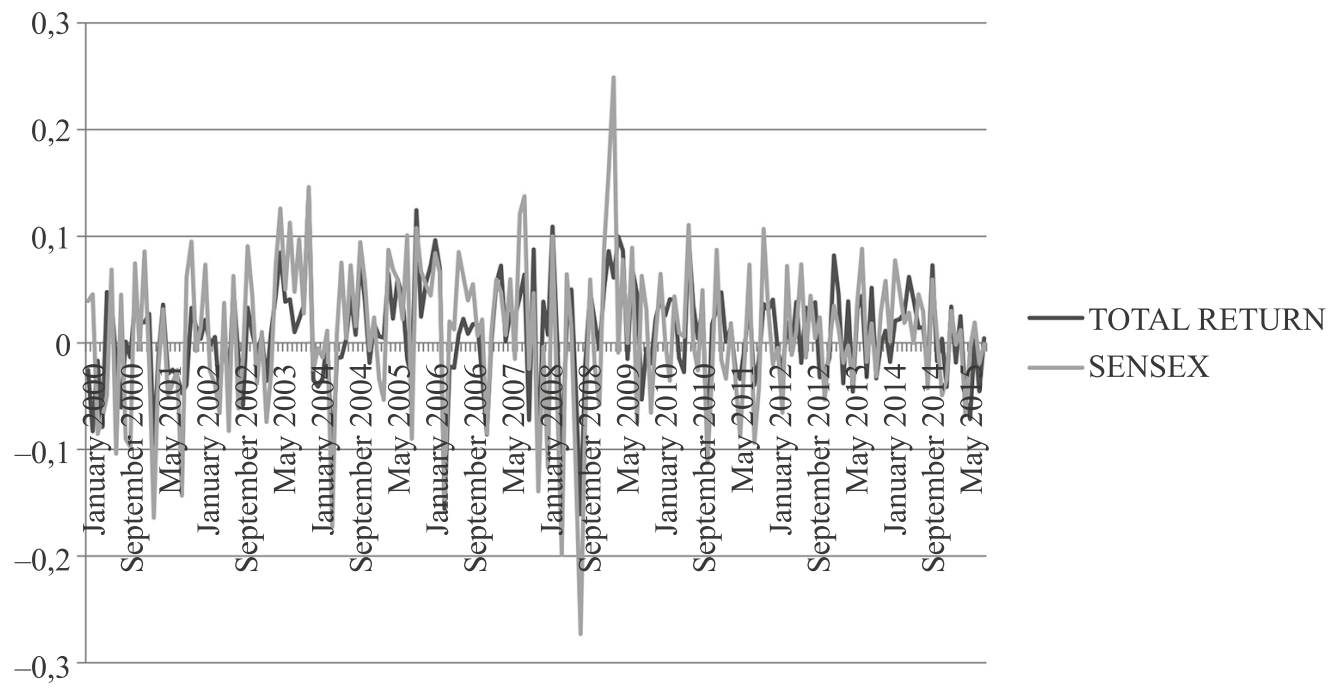

Figure 4. Total return from portfolio vis-a-vis Sensex return during full cycle, January 2000 - December 2015

The tracking error shows 4,9\% deviation from benchmark index which may be due to the defensive characteristic of the portfolio.

Table 8. Portfolio performance evaluation, 2000-2015 (Sharpe ratio and Tracking error)

\begin{tabular}{|l|c|c|c|}
\hline \multicolumn{1}{|c|}{ Particulars } & Portfolio & BSE Sensex & \\
\hline $\begin{array}{l}\text { Excess of average portfolio return over risk free } \\
\text { return }\end{array}$ & 0,045157 & 0,057250 & \\
\hline Standard deviation $(\sigma)$ of portfolio return & 0,202479 & 0,346391 & \\
\hline Sharpe ratio & $\mathbf{0 , 2 2 3 0 2 2}$ & $\mathbf{0 , 1 6 5 2 7 7}$ & \\
\hline Tracking error (monthly) & & & $\mathbf{0 , 0 4 8 8 7}$ \\
\hline
\end{tabular}

\section{CONCLUSIONS}

The above study has attempted to construct well diversified weighted portfolios of securities in Indian context that yield positive returns during different phases of economic situation in the market. It has also tested the efficiency of such constructed portfolios by using Sharpe ratio and tracking error. It may be noted from the analysis that it is possible to earn a positive return even during the slowdown phase of the market, provided proper care is taken in selecting the securities considering their volatility of returns and past returns. The study also suggests that portfolios should be diversified across all categories of Large Cap, Mid Cap and Small Cap stocks based on their 
risk-return characteristics since it is found that even Small Cap stock gets included in the portfolio during the slowdown phase of the market. The weighted portfolios during different phases also reveal a common feature that maximum weight is assigned to the stocks either from FMCG industry or from Pharmaceuticals industry. This may be due to the effect of NREGA initiative which increased the number of potential consumers in the Indian rural sector, and further incentives being provided by the government through favourable taxation policy which made many FMCG companies to make huge investments in the tax-holiday states. This shows that the state support leads to positive long-term reaction of investors which is reflected in the fact that a significant portion of model portfolio according to the criterion of risk-return consists of shares of FMCG companies and this effect was observed at any phase of market situation. On the other hand, Pharmaceutical stocks are always known to be defensive in nature, unlike other sectors which are volatile. Moreover, the weakening of Indian currency has led to export competitiveness of pharmaceutical products. It is also evident from the analysis that while diversifying among stocks, a defensive strategy should be adopted to avoid major losses due to sudden crisis.

Thus the present study has quite significantly constructed portfolios with the most viable securities based on their risk and return characteristics, though it has failed to consider other factors like transaction cost, liquidity, investment horizon etc. which may affect investors' investment choices. Hence, further studies may be carried out considering other aspects like transaction cost, liquidity etc. Additionally, a similar study may also be carried out in other global exchanges to find out whether weights assigned industry wise remains consistent in international markets as well. Moreover, a primary survey among the investors may be done to gain an insight about the different situations and considerations faced by them, and to know which factors affect their portfolio choices.

\section{References}

Barua S. K., Raghunathan V. 1986. Inefficiency of the Indian capital market. Vikalpa 11 (3): 225-229.

Barua S. K., Srinivasan G. 1987. Investigation of decision criteria for investment in risky assets. OMEGA: International Journal of Management Science 15 (3): 247-253.

Barua S.K., Srinivasan G. 1991. Experiment on individual investment decision making process. Sankhya 53 (B): 74-88.

Evans J. L., Archer S.H. 1968. Diversification and the reduction of dispersion: An empirical analysis. Journal of Finance 23: 761-767.

Goetzmann W., Kumar A. 2008. Equity portfolio diversification. Review of Finance 12 (3): 433-463.

Gupta R. 1991. Portfolio Management: The Process and Its Dynamics. Working Paper No. 923. Indian Institute of Management, Ahmedabad, January-March.

Markowitz H. 1952. Portfolio selection. The Journal of Finance 7 (1): 77-91.

Meric I., Ratner M., Meric G. 2008. Co-movements of sector index returns in the world's major stock markets in bull and bear markets: Portfolio diversification implications. International Review of Financial Analysis 17 (1): 156-177.

Sanyal G., Sen S. 1998. Portfolio diversification and risk reduction in India - an empirical analysis. Finance India 12 (2): 375-383. 
Varma J. R. 1991. Is the BSE Sensitive Index Better than the National Index? Working Paper No. 988. Indian Institute of Management, Ahmedabad, October-December.

For citation: Ghosh S., Chakraborty T. Active Investment and Investing Actively: An Empirical Study of Indian Stock Market. Vestnik of Saint Petersburg University. Management, 2018, vol. 17, issue 2, pp. 185-203. https://doi.org/10.21638/11701/spbu08.2018.203

Initial submission: July 3, 2017; recommended for publication: May 16, 2018.

Contact information

Sharmistha Ghosh — PhD; Assistant Professor; sghosh.2008@yahoo.in

Tanupa Chakraborty - PhD; Professor; tanupachakraborty@gmail.com 


\section{LIST OF SELECTED STOCKS}

\begin{tabular}{|c|c|}
\hline S. No. & Categories of sample stocks \\
\hline \multicolumn{2}{|r|}{ Large Cap } \\
\hline 1 & Acc Ltd. \\
\hline 2 & Ambuja Cement \\
\hline 3 & Bharat Heavy Electricals Ltd. \\
\hline 4 & Cipla Ltd. \\
\hline 5 & Dr Reddy's Lab \\
\hline 6 & Gail India Ltd. \\
\hline 7 & Glaxo Smithkline Pharma \\
\hline 8 & Grasim Industries Ltd. \\
\hline 9 & HDFC \\
\hline 10 & HDFC Bank Ltd. \\
\hline 11 & Hero Motor Corporation \\
\hline 12 & Hindalco India Ltd. \\
\hline 13 & Hindustan Petroleum Corporation \\
\hline 14 & HUL \\
\hline 15 & ICICI Bank Ltd. \\
\hline 16 & IDBI Ltd. \\
\hline 17 & Infosys Ltd. \\
\hline 18 & ITC Ltd. \\
\hline 19 & Larsen and Toubro \\
\hline 20 & Mahindra \& Mahindra \\
\hline 21 & Nestle India Ltd. \\
\hline 22 & ONGC Ltd. \\
\hline 23 & Reliance Infra Ltd. \\
\hline 24 & RIL \& RPL \\
\hline 25 & SBI \\
\hline 26 & Sun Pharmaceuticals Industries \\
\hline 27 & Tata Chemicals \\
\hline 28 & Tata Motors Ltd. \\
\hline 29 & Tata Power Co. Ltd. \\
\hline 30 & Tata Steel \\
\hline 31 & Wipro Ltd. \\
\hline 32 & Zee Entertainments Ltd. \\
\hline \multicolumn{2}{|r|}{ Mid Cap } \\
\hline 33 & Indian Hotels Companies Ltd. \\
\hline 34 & Ranbaxy Laboratories (merged with Sun Pharmaceuticals in April 2015) \\
\hline
\end{tabular}


End of the appendix

\begin{tabular}{|l|l|}
\hline \multicolumn{2}{|c|}{ Small Cap } \\
\hline 35 & Mahanagar Telephone Nigam Ltd. \\
\hline \multicolumn{1}{|c|}{ Mid Cap to Large Cap } \\
\hline 36 & Castrol India Ltd. \\
\hline 37 & Colgate Palmolive Ltd. \\
\hline 38 & $\begin{array}{l}\text { Sesa Goa Ltd. (merged with Sesa Sterlite Ltd. in August 2013 and renamed } \\
\text { as Vedanta Ltd. in 2015) }\end{array}$ \\
\hline \multicolumn{2}{|c}{ Small Cap to Mid Cap } \\
\hline 39 & NIIT Ltd. \\
\hline 40 & Novartis India Ltd. \\
\hline
\end{tabular}

